\title{
Spontaneous Locomotor Hyperactivity in a Mouse Mutant with a Deletion Including the Snap Gene on Chromosome 2
}

\author{
E. J. Hess, ${ }^{1}$ H. A. Jinnah, ${ }^{2}$ C. A. Kozak, ${ }^{3}$ and M. C. Wilson ${ }^{1}$ \\ 1Department of Neuropharmacology, The Scripps Research Institute, La Jolla, California 92037, ${ }^{2}$ Department of \\ Neurosciences, University of California, San Diego School of Medicine, La Jolla, California 92093, and '2aboratory of \\ Molecular Microbiology, National Institute of Allergy and Infectious Diseases, NIH, Bethesda, Maryland 20892
}

\begin{abstract}
The gene encoding the synaptosomal-associated protein$25 \mathrm{kDa}$ (SNAP-25) was mapped by analysis of somatic cell hybrids and an intersubspecies backcross to mouse Chromosome 2. To identify potential mutants for SNAP-25, mice bearing mutations mapping to this region of Chromosome 2 were screened for Snap gene abnormalities. Mice heterozygous for the semidominant mutation coloboma $(\mathrm{Cm} /+)$ were identified that carried a deletion of Snap gene sequence. Analysis of genomic DNA revealed that the Snap gene dosage in $\mathrm{Cm} /+$ mice was $50 \%$ lower than control littermates. Additionally, SNAP-25 mRNA and protein expression were $50 \%$ lower in coloboma mice than control littermates. The coloboma mouse phenotype is characterized by small eyes and head bobbing; in addition, we observed that these mice were extremely hyperactive with spontaneous locomotor activity exceeding three times control mouse activity. The localization of the genetic abnormality in coloboma mice using the Snap gene marker will provide a powerful tool for studying the biologic basis of locomotor hyperactivity.
\end{abstract}

Pathologic states of hyperactivity are manifested in a variety of neurological conditions, including manic depressive disorder, some forms of viral encephalopathy, attention deficit hyperactivity disorder (ADHD), and several other organic brain diseases. Animal models of hyperactive behavior are of considerable interest as they provide expcrimental paradigms for assessing the neurologic mechanisms underlying hyperactivity syndromes. Synthetic neurotoxins such as 6-hydroxydopamine, as well as naturally occurring substances such as lead, can produce hyperactivity when administered to young animals (Silbergeld and Goldberg, 1974; Shaywitz et al., 1976). Other studies with animals have demonstrated a genetic predisposition for locomotor hyperactivity. For example, the spontaneously hypertensive rat (SHR) and the inbred mutant mouse weaver dis-

\footnotetext{
Received Jan. 15, 1992; accepted Feb. 26, 1992.

We thank Dr. F. H. Gage for the use of his activity chambers, Drs. F. E. Bloom, N. A. Jenkins, and J. M. Swanson for helpful discussion, and T. M. Slater for technical and computer assistance. We also thank R. Balling and B. Hogan for generously providing PAX-1 and BMP-2a probes, respectively. This work was supported by NIH Grants NS 23038 and CA 33730 to M.C.W., by an American Epilepsy Society research fellowship to E.J.H., and by National Institute for Alcoholism and Alcohol Abuse Grant 07456 to F. E. Bloom. This is manuscript 6856-NP from The Scripps Research Institute.

Correspondence should be addressed to Michael C. Wilson, Ph.D., Department of Neuropharmacology, The Scripps Research Institute, $10666 \mathrm{~N}$. Torrey Pine Road CVN9, La Jolla, CA 92037.

Copyright (C) 1992 Society for Neuroscience $0270-6474 / 92 / 122865-07 \$ 05.00 / 0$
}

play spontaneous hyperactive behavior (Knardahl and Sagvolden, 1979; Schmidt et al., 1982; Roffler-Tarlov and Graybiel, 1984; Wultz et al., 1990). However, the genes responsible for this behavior have not been identified. Clearly, characterization of a specifically defined genetic locus would provide a more accessible model for investigating hyperactivity at the molecular level.

Here, we describe the identification of a spontaneously hyperactive mouse mutant coloboma bearing a deletion within mouse Chromosome 2 ( $\mathrm{Chr} 2$ ). This deletion spans the gene for SNAP-25 (synaptosomal-associated protein), a $25 \mathrm{kDa}$ protein differentially expressed in subsets of neuronal populations, including those of the neocortex, hippocampus, anterior thalamic nuclei, and cerebellar granule cells (Oyler et al., 1989). Ultrastructural analysis has localized this neuron-specific protein to presynaptic nerve terminals, and more recently, SNAP- 25 has been identified as "super protein," a major protein conveyed by fast axonal transport (Luewy et al., 1991; D. T. Hess, T. M. Slater, M. C. Wilson, and J. H. P. Skene, unpublished observations). During development, induction of SNAP-25 expression correlates precisely with the onset of synaptogenesis (Catsicas et al., 1991; Oyler et al., 1991), and in the adult, SNAP-25 expression is induced during synaptic remodeling (Geddes et al., 1990). While the remarkably high conservation of SNAP-25 across species (Catsicas et al., 1991) suggests that it plays an important role in synaptic structure and/or function, the function of SN $\Lambda \mathrm{P}-25$ at the synaptic terminal is unknown.

One method for determining the function of a protein is through the identification of a mutant. To this end, we have mapped the Snap gene, encoding the SNAP-25 protein, to a mouse chromosome and determined that the mouse mutant coloboma bears a chromosomal deletion that spans at least the entire Snap gene. We have found that the phenotypic expression of this deletion includes profound spontaneous locomolor hyperactivity that may provide a novel animal model for examining the neurobiologic basis of hyperactivity syndromes.

\section{Materials and Methods}

Mouse mutants. Eight- to ten-week-old coloboma $(\mathrm{Cm} /+)$ mice and control $(+/+)$ littermates were purchased from The Jackson Laboratory (Bar Harbor, ME). The coloboma mutation that first arose on a $\mathrm{C} 3 \mathrm{H} / \mathrm{HeH} \times 101 / \mathrm{H} \mathrm{Fl}$ male had been bred onto the C57BL/6By background for 32 generations. The mutation has since been maintained by backcrosses onto the $\mathrm{C} 3 \mathrm{H} / \mathrm{HeSnJ}$ strain for 10 generations by $\mathrm{M}$. Davisson at The Jackson Laboratory. After backcrossing a mutation into a new strain for 10 generations, $99.8 \%$ of unlinked genes in the mutant genome originate from the backcross strain (E. L. Green, 1981a). In all experiments, coloboma mouse mutants were compared to their normal 
control littermates derived from backcrossing $\mathrm{Cm} /+$ mice with wildtype C3H/HeSnJ mice. All other mouse mutants tested for Snap mutations including wellhaarig (we), mahogany $(\mathrm{mg})$, lethal milk $(\mathrm{lm})$, undulated $(u n)$, blind-sterile $(b s)$, and brachypodism $(b p)$ were also purchased from The Jackson Laboratory.

Genetic mapping. Twenty-four Chinese hamster $\times$ mouse somatic cell hybrids were selected from a larger panel of 76 hybrids described and characterized previously (Hoggan et al., 1988). Thirteen hybrids were typed for mouse chromosomes by karylogy; the rest were typed for markers on specific chromosomes.

Two genetic crosses were used for mapping. For the first cross, NFS/N females were mated with Mus m. musculus (Skive) males and the F1 progeny were mated with $M$. m. musculus as previously described (Kozak et al., 1990). DNAs extracted from individual backcross progeny were typed by Southern analysis with SNAP-25 probe following digestion with Scal as well as for other genetic markers including $H d c$ (histidine decarboxylase) typed using a rat HDC cDNA probe (Joseph et al., 1990) following digestion with XbaI, and $E m v-15$ (endogenous ecotropic leukemia virus-15) typed following digestion with HindIII. The Emv-15 probe was kindly provided by Dr. G. Barsh (University of California, San Francisco) and represents a 1.1 kilobase (kb) EcoRI fragment (Lovett et al., 1987). For the second cross, NFS/N females were mated with $M$. spretus males and the $F 1$ females were mated with M. spretus or C58/J (Adamson et al., 1991). DNAs from individual backcross progeny were typed for Snap using BamHI, for $H d c$ using EcoRI, and for Emv-15 using HindIII.

Interspecific and interstrain crosses. $M$. spretus males purchased from The Jackson Laboratory (Bar Harbor, ME) were mated with $M . m$. musculus $\mathrm{Cm} / \mathrm{C} 3 \mathrm{H} / \mathrm{HeSnJ}$ females. The progeny of this interspecific cross were identified as $+/+$ or $\mathrm{Cm} /+$ by eye morphology; the Fl $\mathrm{Cm} /+$ mice were easily identified by their small eyes. DNAs extracted from both parent mice and a $+/+$ and $\mathrm{Cm} /+\mathrm{F} 1$ mouse were examined by Southern analysis with a SNAP-25 probe following digestion with EcoRI and with a BMP-2a (bone morphogenetic protein-2a) probe synthesized from the murine BMP-2a cDNA (Lyons et al., 1989) provided by B. Hogan (Vanderbilt University) following digestion with $\mathrm{XbaI}$. For the interstrain cross, a $\mathrm{C} 3 \mathrm{H} / \mathrm{HeSnJ} \mathrm{Cm} /+$ male was crossed with a C57BL/ $6 \mathrm{~J}$ female and the progeny of the cross identified as $+1+$ or $\mathrm{Cm} /+$ as described above. DNAs extracted from both parent mice and a $+1+$ and $\mathrm{Cm} /+\mathrm{F} 1$ mouse were examined by Southern analysis with a murine PAX-1 cDNA probe (Deutsch et al., 1988) kindly provided by R. Balling (Max Planck Institute of Biophysical Chemistry) following digestion with PstI.

Genomic Southern analysis and slot blots. The probe for Snap hybridizations was prepared from an 881 base pair (bp) SNAP-25 cDNA comprised of the entire 618 bp open reading frame plus $5^{\prime}$ untranslated sequence. Control and coloboma mouse genomic DNA was prepared by digesting $2 \mathrm{~cm}$ clips of mouse tail in $500 \mu \mathrm{g} / \mathrm{ml}$ buffered [ $50 \mathrm{mM}$ Tris (pH 8.0), 100 mm EDTA, $100 \mathrm{~mm} \mathrm{NaCl}, 1 \%$ SDS] proteinase K for 16 $\mathrm{hr}$ at $56^{\circ} \mathrm{C}$. Digests were extracted with phenol and chloroform, precipitated in ethanol, and resuspended in sterile water. Each tail clip produccd $\sim 100 \mu \mathrm{g}$ of genomic DN $\Lambda$.

For slot blots, control or coloboma mouse genomic DNA was denatured for $30 \mathrm{~min}$ at $67^{\circ} \mathrm{C}$ in $200 \mu \mathrm{l}$ of $10 \mathrm{mM}$ Tris (pH 8.0), $1 \mathrm{~mm}$ EDTA, $0.3 \mathrm{~m} \mathrm{NaOH}$, cooled on ice, and neutralized with an equal volume of $2 \mathrm{~m}$ ammonium acetate ( $\mathrm{pH} 7.0$ ). DNA masses for all samples were equalized to $4 \mu \mathrm{g}$ of DNA per slot with the addition of lambda phage DNA. Additionally, a control sample containing $4 \mu \mathrm{g}$ of lambda DNA only was prepared. Samples from individual mice were slot blotted onto nitrocellulose, and the filter was air dried and baked at $80^{\circ} \mathrm{C}$ for 2 hr. This experiment was repeated four times using DNA from four individual control and coloboma mice.

For mouse genomic Southern blots, $10 \mu \mathrm{g}$ of control or coloboma mouse genomic DNA were digested with the appropriate restriction endonuclease and resolved on a $0.7 \%$ agarose gel. For mouse $\times$ hamster somatic cell hybrid Southern analysis, $10 \mu \mathrm{g}$ of DN $\Lambda$ from 24 mouse $x$ hamster cell lines containing various mouse chromosomes were digested with EcoRI and size fractionated on a $0.7 \%$ agarose gel. After hydrolysis, denaturation, and neutralization, the DNA was transferred to nylon membrane (Zetabind, CUNO Inc., Meriden, CT) and baked at $80^{\circ} \mathrm{C}$ for $2 \mathrm{hr}$.

Slot blot and Southern blot filters were prehybridized for $16 \mathrm{hr}$ at $67^{\circ} \mathrm{C}$ in $3 \times$ TESS $(0.45 \mathrm{M} \mathrm{NaCl}, 15 \mathrm{~mm}$ TES [2-(tris-[hydroxymethyl]methyl)-amino ethanesulfonic acidl, $15 \mathrm{~mm}$ EDTA), $5 \times$ Denhardt's solution, $0.2 \%$ SDS, 2 mM sodium pyrophosphate, and $100 \mu \mathrm{g} / \mathrm{ml} \mathrm{sal-}$ mon sperm DNA. Filters were hybridized at $67^{\circ} \mathrm{C}$ for $20 \mathrm{hr}$ with random- primed ${ }^{32} \mathrm{P}$-labeled probe to SNAP-25 in prehybridization solution plus $10 \%$ dextran sulfate. Blols were washed to a final stringency of $0.1 \times$ SSC ( $1 \times$ SSC: $0.15 \mathrm{M} \mathrm{NaCl}, 0.015 \mathrm{M}$ sodium citrate $), 0.1 \% \mathrm{SDS}$ at $67^{\circ} \mathrm{C}$ and apposed to film for 3-7 d. For slot blots only, after SNAP-25 hybridization, probe was boiled off and the same blots were hybridized with random primed ${ }^{32} \mathrm{P}$-labeled probe prepared from a cDNA comprising $740 \mathrm{bp}$ of the murine $\beta$-amyloid precursor protein open reading frame (G. A. Higgins, G. A. Oyler, and M. C. Wilson, unpublished observations) as an internal control for mass of genomic DNA blotted. Film optical density was quantitated on a laser densitometer (Pharmacia-LKB).

Ribonuclease protection assay. Control and coloboma mice were killed by decapitation, the brains removed, and total cellular RNA isolated using the guanidinium thiocyanate/ $\mathrm{CsCl}$ centrifugation procedure (Chirgwin et al., 1979). Appropriate masses of total RNA were hybridized overnight at $42^{\circ} \mathrm{C}$ in $80 \%$ formamide, $40 \mathrm{~mm}$ PIPES (piperazine$N, N^{\prime}$-bis-[2-ethane sulfonic acid]; pH 6.4), 400 mm sodium acetate, and $1 \mathrm{mM}$ EDTA with $5 \times 10^{4} \mathrm{cpm}$ of a $400 \mathrm{bp} \mathrm{SNAP-25} \mathrm{cRNA}$ and $5 \times$ $10^{4} \mathrm{cpm}$ of a $250 \mathrm{bp} \beta$-actin cRNA. Samples were then digested with an RNase A/RNase T1 mix for 30 min at $37^{\circ} \mathrm{C}$, digested with Proteinase $\mathrm{K}$ for $15 \mathrm{~min}$ at $37^{\circ} \mathrm{C}$, extracted with phenol/chloroform/isoamyl alcohol (25:24:1), and ethanol precipitated. Samples were resuspended and size fractionated on a denaturing $5 \%$ polyacrylamide gel, and the gel was apposed to x-ray film (XAR, Kodak) for $2-5 \mathrm{hr}$.

In situ hybridization. The in situ hybridization procedure has been described in detail (Wilson and Higgins, 1989). ${ }^{35} \mathrm{~S}$-labeled single-stranded antisense RNA probes were generated from cDNAs of murine SN $\Lambda P$ 25 and $\beta$-amyloid precursor protein subcloned in pBluescript as described above. After in vitro transcription, the DNA template was removed by digestion with RNase-free DNase (Promega) and the transcripts were sized reduced to $150-250$ nucleotides by alkali treatment.

Pretreatment of the slide-mounted sections included fixation in buffered $4 \%$ formaldehyde for $5 \mathrm{~min}$ at room temperature, followed by treatment with $25 \mu \mathrm{g} / \mathrm{ml}$ proteinase $\mathrm{K}$ in $5 \times \mathrm{TE}$ ( $50 \mathrm{mM}$ Tris, $\mathrm{pH} 8.0$, $5 \mathrm{~mm}$ EDTA) for $7.5 \mathrm{~min}$ at $37^{\circ} \mathrm{C}$, treatment in $0.5 \mathrm{~N} \mathrm{HCl}$ for $7.5 \mathrm{~min}$ at room temperature, and a final $5 \mathrm{~min}$ postfixation in buffered $4 \%$ formaldehyde. Slides were rinsed $2 \times 2 \mathrm{~min}$ in PBS between each of the aforementioned steps. Sections were then dehydrated in graded ethanols and air dried.

Slides were prehybridized at $52^{\circ} \mathrm{C}$ for $2-3 \mathrm{hr}$ in approximately 750 $\mu l$ of a solution containing $50 \%$ formamide, $0.75 \mathrm{M} \mathrm{NaCl}, 20 \mathrm{~mm}$ PIPES, pH $6.8,10 \mathrm{~mm}$ EDTA, $10 \%$ dextran sulfate, $5 \times$ Denhardt's solution (0.02\% BSA, $0.02 \%$ ficoll, $0.02 \%$ polyvinylpyrolidone), $50 \mathrm{~mm}$ dithiothreitol, $0.2 \%$ SDS, and $100 \mu \mathrm{g} / \mathrm{ml}$ each salmon sperm DNA and yeast tRNA. Prehybridization buffer was removed from the slides, and $75 \mu \mathrm{l}$ of hybridization solution consisting of prehybridization buffer plus 10 ng probe were applied to each slide. Slides were coverslipped and hybridized for $16 \mathrm{hr}$ at $52^{\circ} \mathrm{C}$.

Following hybridization, coverslips were removed in $4 \times \operatorname{SSC}(0.15$ $\mathrm{M} \mathrm{NaCl}, 0.015 \mathrm{M}$ sodium citrate) plus $300 \mathrm{~mm} 2$-mercapthoethanol at room temperature, incubated in this solution for $15 \mathrm{~min}$, and incubated in $4 \times$ SSC without 2-mercaptoethanol for $15 \mathrm{~min}$ at room temperature. Sections were treated with $50 \mu \mathrm{g} / \mathrm{ml}$ pancreatic RNase A in $0.5 \mathrm{M} \mathrm{NaCl}$, $50 \mathrm{~mm}$ Tris, $\mathrm{pH} 8.0,5 \mathrm{~mm}$ EDTA for $30 \mathrm{~min}$ at $37^{\circ} \mathrm{C}$, rinsed for 30 min at $37^{\circ} \mathrm{C}$ in this same buffer, washed in $2 \times \mathrm{SSC}$ at $56^{\circ} \mathrm{C}$ for $15 \mathrm{~min}$, and air dried. Sections were exposed to x-ray film (Du Pont Cronex) for $2-4 \mathrm{~d}$.

Protein slot blots. Control and coloboma mice were killed by decapitation and the brains removed. Brain proteins were extracted from whole brain in $1 \%$ NP-40, methanol precipitated, and resuspended in $1 \%$ SDS. Protein concentrations were determined using the Pierce Micro BCA protein assay, which accommodates the presence of SDS. Proteins were diluted to appropriate concentrations in PBS, and $100 \mu \mathrm{l}$ of each dilution were slot blotted onto nitrocellulose. Nitrocellulose blots were incubated for $30 \mathrm{~min}$ in $10 \%$ acetic acid, rinsed briefly in PBS, and blocked overnight in Blotto [0.16 $\mathrm{M} \mathrm{NaCl}, 10 \mathrm{~mm}$ sodium phosphate (pH 7.5), $0.01 \%$ Thimerosal, 5\% (w:v) nonfat dry milk, $0.006 \%$ (v:v) antifoam A]. Blots were then incubated in a 1:400 dilution of peptidedirected SNAP-25 antisera (described in Oyler et al., 1989) in Blotto for $3 \mathrm{hr}$ at room temperature, washed three times in Blotto at room temperature, and incubated for $1 \mathrm{hr}$ at room temperature in Blotto with 125I-labeled Staphylococcus protein A. Blots were rinsed in water and apposed to film for $16 \mathrm{hr}$. Film optical density was quantitated on a laser densitometer (Pharmacia-LKB).

Behavioral testing. All mice used in the behavioral tests were obtained from The Jackson Laboratories where they were identified as $\mathrm{Cm} /+$ or 
Table 1. Segregation of the Snap hybridizing restriction fragment with alleles of $H d c$ and $E m v-15$ in progeny of an intersubspecies and interspecies backcross

\begin{tabular}{|c|c|c|c|c|c|}
\hline \multirow[b]{2}{*}{ Mice } & \multicolumn{3}{|c|}{$\begin{array}{l}\text { Inheritance of alleles } \\
\text { from the F1 parent }\end{array}$} & \multicolumn{2}{|c|}{ Number of mice } \\
\hline & $H d c$ & Snap & $\begin{array}{l}E m v- \\
15\end{array}$ & $\begin{array}{l}\text { Cross } \\
1\end{array}$ & $\begin{array}{l}\text { Cross } \\
2\end{array}$ \\
\hline \multirow[t]{2}{*}{ Nonrecombinants } & + & + & + & 20 & 38 \\
\hline & - & - & - & 21 & 31 \\
\hline \multirow[t]{5}{*}{ Single recombinants } & + & + & - & 4 & 2 \\
\hline & - & - & + & 2 & 5 \\
\hline & + & - & - & 4 & 3 \\
\hline & - & + & + & 1 & $\underline{2}$ \\
\hline & & & & 52 & 81 \\
\hline
\end{tabular}

Table 2. Recombination

\begin{tabular}{lll} 
Locus pair & $r / n$ & $\begin{array}{l}\text { Recombination } \\
(\% \pm \mathrm{SE})\end{array}$ \\
\hline Hdc, Snap & $10 / 133$ & $7.5 \pm 2.3$ \\
Snap, Emv-15 & $13 / 133$ & $9.8 \pm 2.6$
\end{tabular}

Percentage recombination between restriction fragments and SE were calculated according to E. L. Green (1981b) from the number of recombinants $(r)$ in a sample size of $n$.

$+/+$ mice using eye morphology as the phenotypic criterion for genotype determination. Mice were maintained in group cages on ad lib food and water with a $12 \mathrm{hr}$ light $/ 12 \mathrm{hr}$ dark cycle (6 A.M., 6 P.M.). Male $\mathrm{Cm} /+$ mice $(n=5)$ and control littermates $(n=5)$ on a C3H/HeSnJ background were placed in individual Plexiglas open field photocell activity cages $(60 \times 60 \times 40 \mathrm{~cm})$ with four $2-\mathrm{cm}$-high infrared beam detectors per side. Recordings started at 10:00 A.M. and continued for $24 \mathrm{hr}$ with beak breaks accumulated every $15 \mathrm{~min}$. Mice were provided with food and water during the entire testing session. Activity data were analyzed by two-factor repeated-measures ANOVA, and time spent quiescent was analyzed by a Student's $t$ test.

\section{Results}

Genetic mapping of Snap. To map the Snap gene to a mouse chromosome, a panel of 24 mouse $\times$ hamster hybrid cell lines containing different mouse chromosomes was screened by Southern analysis using a SNAP-25 cDNA. All cell lines were positive for hamster Snap, and 13 of the hybrids were positive for murine Snap; the mouse chromosome content of these cell lines suggested that Snap was located on mouse Chr 2.

The Snap gene was more precisely localized on mouse Chr 2 by Southern blot analysis of the progeny from two genetic crosses. In the first cross, DNA from progeny of the matings (NFS/N $\times M . m$. musculus) $\times M . m$. musculus was digested with ScaI and hybridized with a SNAP-25 cDNA probe, distinguishing $M$. m. musculus Snap fragments of $12.8,6.0$, and $2.9 \mathrm{~kb}$ from 18.5 and $8.2 \mathrm{~kb}$ NFS/N fragments. In the second cross, DNA from progeny of the matings $(\mathrm{NFS} / \mathrm{N} \times M$. spretus $) \times M$. spretus or C58/J was digested with BamHI and hybridized with a SNAP25 cDNA probe, distinguishing an $M$. spretus Snap fragment of $23 \mathrm{~kb}$ from a $28 \mathrm{~kb} \mathrm{NFS} / \mathrm{N}$ or C $58 / \mathrm{J}$ fragment. Analysis of the backcross mice identified 67 of 133 progeny bearing the F1 parental Snap allele consistent with the 1:1 segregation ratio expected for a single gene. When Snap segregation was compared with the Chr 2 markers $H d c$ and $E m v$-15, 10 recombination
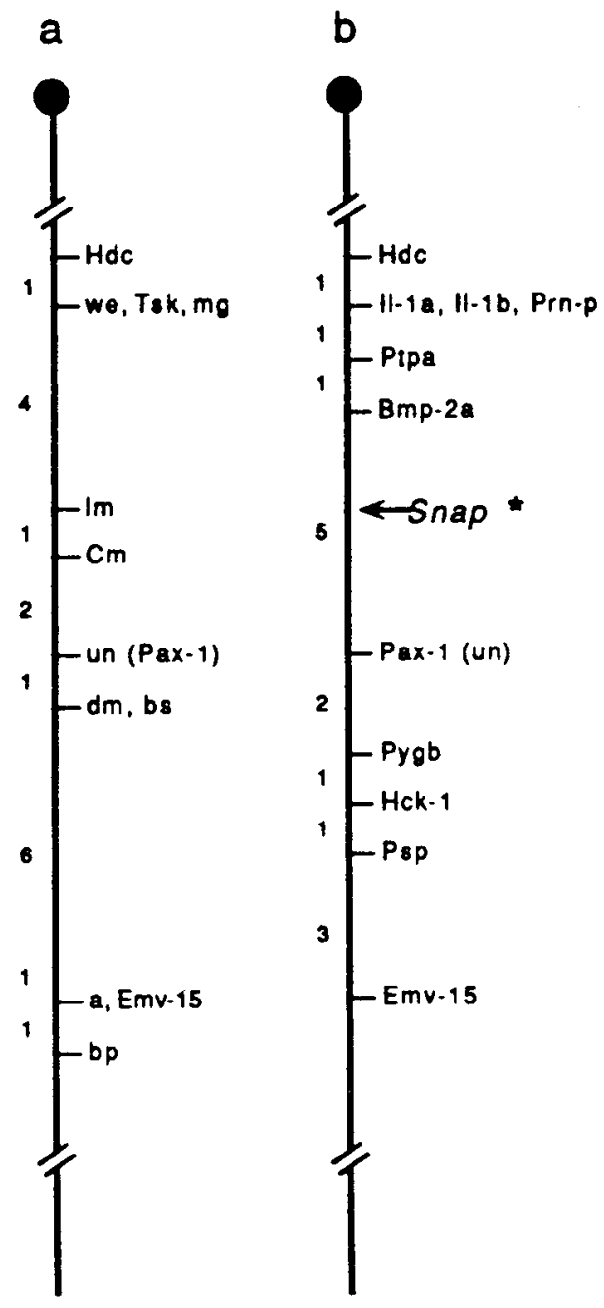

Figure 1. Genetic (a) and molecular (b) maps of the medial portion of mouse $\mathrm{Chr} 2$. Mouse mutants mapping between the markers $H d c$ and $E m v-15$ are illustrated on the genetic map $(a)$ constructed by Lyon and Kirby (1991). All genes between $H d c$ and $E m v-15$ that have been mapped using molecular probes are located on the map $(b)$ constructed by Siracusa and Abbott (1991). Snap was located on the molecular map using relative distances between $H d c$ and $E m v-15$ established from the mapping data.

events were observed between $S n a p$ and $H d c$ and 13 were observed between Snap and Emv-15 (Tables 1 and 2). Recombination frequencies together with the known map location of $H d c$ and $E m v-15$ established the gene order: $H d c-7.5 \pm 2.3$ $\mathrm{cM}-$ Snap-9.8 $\pm 2.6 \mathrm{cM}-E m v-15$.

After the chromosome location had been determined, several mouse mutants previously mapped to this region (Fig. 1a), including we, $m g, l m, C m$, un, $b s$, and $b p$ (Hillyard et al., 1991; Lyon and Kirby, 1991), were screened for Snap restriction fragment length polymorphisms (RFLPs) by Southern analysis of EcoRI-digested genomic DNA. No differences were observed in the Snap restriction fragments in any mouse mutant tested (data not shown). However, reduced Snap hybridization was noted in mice heterozygous for the semidominant mutation coloboma $(\mathrm{Cm} / \mathrm{+})$.

Coloboma mouse genomic DNA. Because weak Snap hybridization was observed in $\mathrm{Cm} /+$ mouse genomic DNA, coloboma mutants were examined more rigorously. As homozygous $\mathrm{Cm} /$ $\mathrm{Cm}$ mice have been reported to die early in embryogenesis 

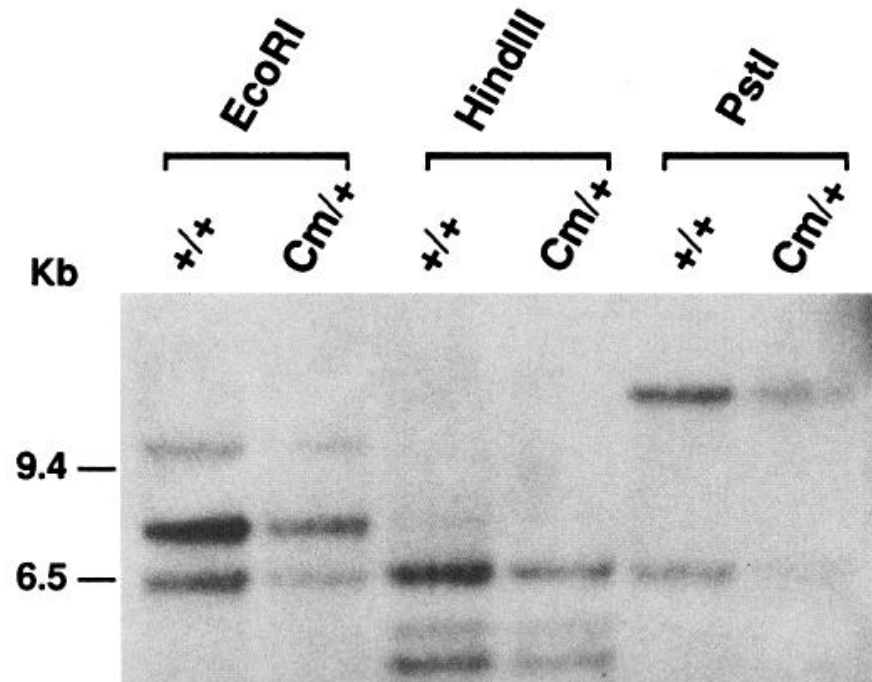

$4.4-$

$2.3-$

$2.0-$
Figure 2. Genomic Southern analysis of SNAP-25 hybridization in control $(+/+)$ and coloboma $(\mathrm{Cm} /+)$ mice. Genomic DNA $(10 \mu \mathrm{g} /$ lane $)$ was digested with EcoRI, HindIII, or PstI, electrophoresed, and transferred to nylon membrane. Filters were hybridized with a ${ }^{32} \mathrm{P}$-labeled random-primed probe to a SNAP-25 cDNA comprised of the entire open reading frame and most of the $5^{\prime}$ untranslated sequence.

(Theiler and Varnum, 1981), only heterozygous $\mathrm{Cm} /+$ mice could be screened. Genomic DNA from $\mathrm{Cm} /+$ mice or their normal littermates $(+/+)$ was digested with several restriction endonucleases, blotted, and probed with a SNAP- 25 cDNA that included the $5^{\prime}$ untranslated region and entire open reading frame. No RFLPs were detected between mutant and control mouse DNA digested with EcoRI, HindIII, or PstI (Fig. 2); however, the intensity of the Snap signal from the coloboma DNA appeared consistently lower than that of control mice. To quantitate more accurately possible differences in Snap gene dosage between control and coloboma mice, slot blots of genomic DNA from $+/+$ mice and $\mathrm{Cm} /+$ mice were compared. Densitometric units quantitated by laser densitometry from the slot blot autoradiographs plotted against mass of DNA/slot revealed that SNAP-25 hybridization to coloboma genomic DNA was approximately $50 \%$ that of control mouse DNA (Fig. 3). In contrast, when the same blot was reprobed with a $\beta$-amyloid precursor protein cDNA, the gene which maps to Chr 16, hybridization was comparable between mutant and control mice. The nearly identical slopes of mutant and control mice in the $\beta$-amyloid precursor protein plot verified that equal masses of mutant and control DNA were blotted. The lack of observable RFLPs in the Southern analysis coupled with the $50 \%$ reduction in Snap hybridization observed in the slot blots suggests that most, if not all, of one copy of the Snap gene is deleted in the $\mathrm{Cm} /+$ mouse.

The gene dosage determined from the slot blot genomic analysis was verified using the progeny of the interspecific $M . m$. musculus $\mathrm{Cm} /+\times$ M. spretus $+/+$ cross. The genetic variation distinguished by restriction endonuclease cleavage sites between these two mouse species made it likely that Southern analysis would reveal specific parental $M$. m. musculus $(\mathrm{C} 3 \mathrm{H} / \mathrm{HeSnJ})$ and $M$. spretus alleles. Indeed, Southern analysis of EcoRI-digested DNA probed with SNAP-25 distinguished a $3.2 \mathrm{~kb} M$. m. musculus-specific RFLP that was not detected in $M$. spretus (Fig. $4 a$, arrow). In the phenotypically normal $(+/+)$ mice of this cross, the $M . m$. musculus Snap allele was present along with the $M$. spretus allele (Fig. 4a). However, the M. m. musculus-specific $3.2 \mathrm{~kb}$ band was not detected in the DNA from the $\mathrm{Cm} /+$ interspecific mouse, identified by ocular deformation, indicating that the $M$. m. musculus Snap allele is deleted in the coloboma interspecific mouse (Fig. 4a). These data confirmed the results of the genomic slot blot analysis, which indicate that the entire Snap gene is deleted from one $\mathrm{Cm} /+\mathrm{Chr} 2$.

Deletion mapping. Based on the estimated position of Snap relative to $E m v-15$ and $H d c$ and the previously mapped location of $\mathrm{Cm}$, we examined two genes within this same region (Pax-1 and $B m p-2 \mathrm{a} ;$ Fig. $1 b)$ as molecular markers to define the outer limits of the coloboma deletion. The integrity of these genes in the coloboma mouse mutant was assessed using RFLPs exhibited in an interspecific $(+/+M$. spretus $\times \mathrm{Cm} /+\mathrm{M} . \mathrm{m}$. musculus) cross for Bmp-2a or an interstrain cross $(\mathrm{Cm} /+\mathrm{C} 3 \mathrm{H} /$ $\mathrm{HeSnJ} \times+/+\mathrm{C} 57 \mathrm{BL} / 6 \mathrm{~J}$ ) for Pax-1. Southern analysis of XbaIdigested DNA from the interspecies cross probed with BMP-2a cDNA (Lyons et al., 1989) revealed a $4.6 \mathrm{~kb}$ M. m. musculusspecific RFLP that was not detected in M. spretus (Fig. $4 b$, arrow). The $M . m$. musculus-specific band was also present in the DNA from both the $+/+$ and $\mathrm{Cm} /+$ interspecific mice, indicating that the $B m p$-2a gene is not included in the coloboma deletion. To determine whether Pax-1 was deleted in the coloboma mutation, DNA from the interstrain cross $\mathrm{Cm} /+\mathrm{C} 3 \mathrm{H} /$ $\mathrm{HeSnJ} \times+/+\mathrm{C} 57 \mathrm{BL} / 6 \mathrm{~J}$ was digested with PstI and probed with the PAX-1 cDNA (Deutsch et al., 1988). A $7.5 \mathrm{~kb}$ band present in the $\mathrm{C} 3 \mathrm{H} / \mathrm{HeSnJ}$ mouse DNA was distinguished from the $1.5 \mathrm{~kb}$ band observed in the C57BL/6J mouse DNA. The $7.5 \mathrm{~kb} \mathrm{C} 3 \mathrm{H} / \mathrm{HeSnJ}-$ specific band was also detected in the DNA of both the $+/+$ and $\mathrm{Cm} /+$ mice produced from the interstrain cross (Fig. $4 c$, arrow), suggesting that $P a x-1$, like $B m p-2 \mathrm{a}$, is not deleted in the coloboma mutation.

SNAP-25 mRNA expression in coloboma mice. Quantitative ribonuclease protection assays were performed to determine if the half gene dose of Snap in coloboma mice affects SNAP-25 mRNA expression. For ribonuclease protection assays, total RNA from mutant and control brains was assayed with probes to SNAP-25 and $\beta$-actin, and the resulting autoradiograph was quantitated by laser densitometry (Fig. 5). SNAP-25 mRNA expression was approximately $50 \%$ lower in the mutant than in its control littermate, while $\beta$-actin expression was comparable in mutant and control mice. These results suggest that, in coloboma mice, the loss of one Snap allele results in a $50 \%$ reduction in the SNAP-25 transcript without affecting other messages such as $\beta$-actin. 

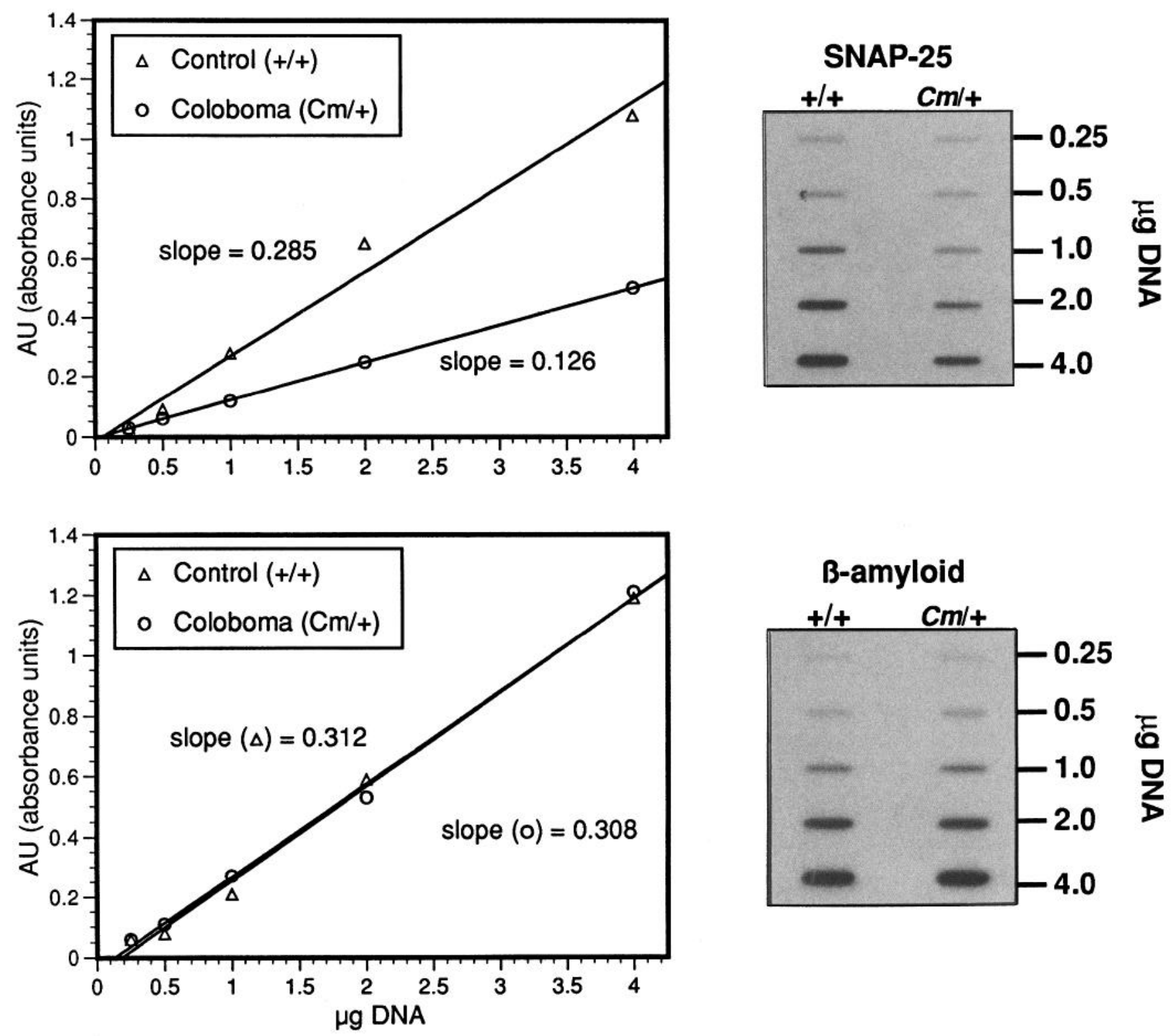

Figure 3. Slot blots of genomic DNA from a control $(+/+)$ and a coloboma mouse. Increasing masses of genomic DNA were blotted to nitrocellulose, hybridized with a ${ }^{32} \mathrm{P}$-labeled probe to SNAP-25 or $\beta$-amyloid precursor protein, and apposed to $\mathrm{x}$-ray film. Autoradiographs were quantitated using a laser densitometer, and the arbitrary absorbance units were plotted against the mass of genomic DNA loaded in the slot. In the top panel, SNAP-25 hybridization in the $\mathrm{Cm} /+$ mouse is $44 \%$ of the $+/+$ mouse; in the bottom panel, where the same blot was rehybridized with $\beta$-amyloid precursor protein, hybridization between the $+/+$ and the $\mathrm{Cm} /+$ mouse is equal. On average, $\mathrm{Cm} /+$ hybridization was $45 \pm 4 \%$ of the $+/+$ SNAP-25 hybridization $(n=4)$.

Neuroanatomical SNAP-25 localization. Consistent with the ribonuclease protection assay, in situ hybridization also indicated that SNAP-25 mRNA expression was reduced in coloboma mouse mutants (Fig. 6), while $\beta$-amyloid precursor protein mRNA expression was comparable between mutant and control mice. Although SNAP-25 expression was reduced in coloboma mice, the neuron-specific pattern of SNAP-25 expression was identical in $\mathrm{Cm} /+$ and $+/+$ mice. Both controls and mutants expressed high levels of SNAP-25 in the hippocampal formation, particularly in CA3 pyramidal cells, cortex, anterior thalamus, and septal nuclei. Moderate SNAP-25 expression was observed in the ventral posterior and ventral lateral thalamic nuclei, while low levels of SNAP-25 mRNA were observed in the basal ganglia. SNAP-25 hybridization was not observed in white matter, consistent with the neuron-specific expression of this mRNA. More detailed descriptions of the distribution of SNAP-25 mRNA by in situ hybridization have been reported previously for both brain (Oyler et al., 1989) and retina (Catsicas et al., 1991). Additionally, neither the SNAP25 nor $\beta$-amyloid precursor protein pattern of hybridization revealed any obvious neuroanatomic abnormalities in the coloboma mouse brain such as cell loss or ectopias observed in other neurological mouse mutants including weaver, reeler, and leaner (M. C. Green, 1981). Thus, the coloboma mutation results in a $50 \%$ reduction specifically in SNAP- 25 mRNA without affecting its normal tissue distribution.

$S N A P-25$ protein expression in coloboma mice. It was important to determine whether the $50 \%$ reduction in SNAP- 25 
a

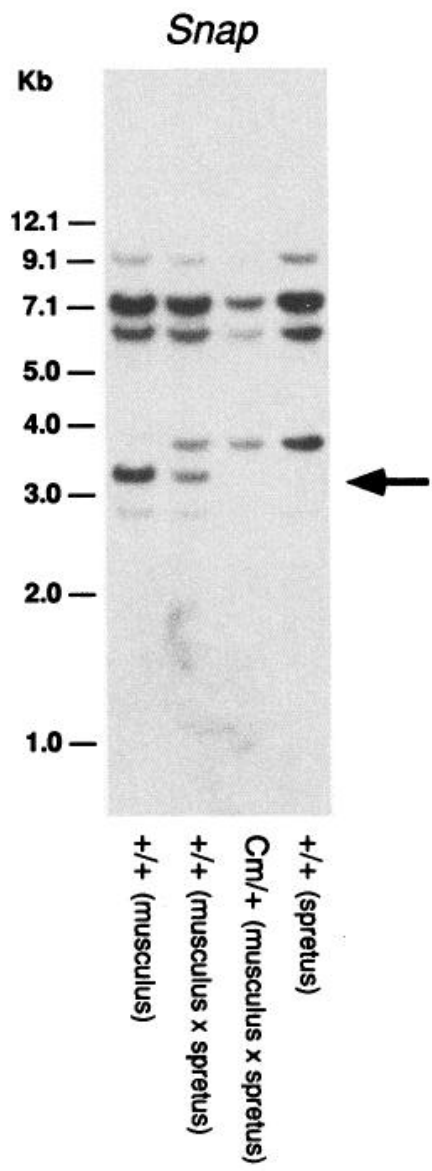

b

Bmp-2a

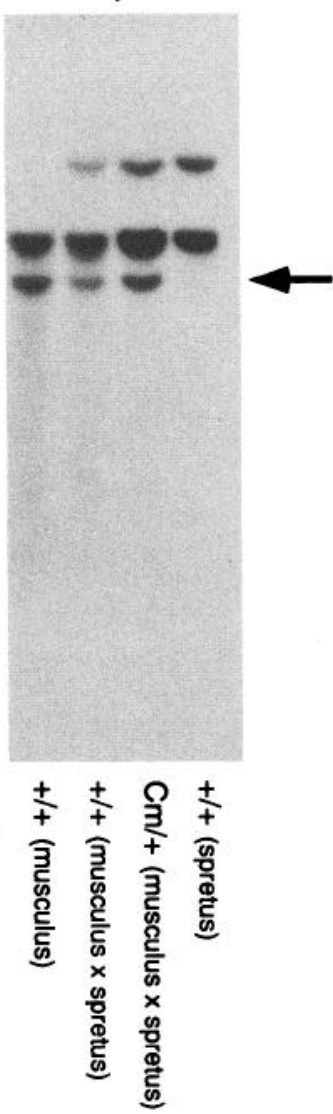

C

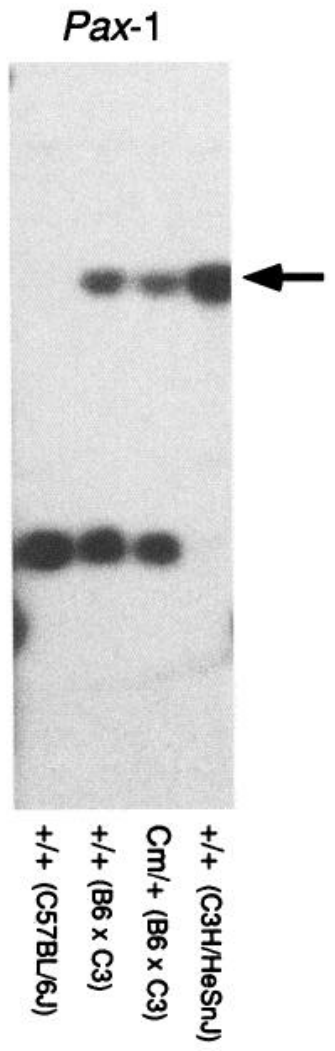

Figure 4. Southern analysis of interspecies or interstrain crosses of coloboma mice. Southern analysis of the two mouse species tested distinguished a $3.2 \mathrm{~kb} M$. m. musculus-specific Snap RFLP that was not detected in $M$. spretus (a, arrow). This Snap M. m. musculus-specific band was not present in the DNA from the $\mathrm{Cm} /+$ interspecific mouse, indicating that the $M . m$. musculus Snap allele is deleted in the coloboma interspecific mouse. The integrity of genes mapping near Snap in the coloboma mouse mutant was assessed by Southern analyses of interspecific $(+/+M$. spretus $\times \mathrm{Cm} /+M$. m. mus culus) or interstrain crosses. The interspecies cross revealed that $B m p-2 \mathrm{a}$ is not deleted in the coloboma mutation (b) as the $M$. musculus-specific RFLP (indicated by an arrow) is present in the $\mathrm{Cm} /+\mathrm{M}$. musculus $\times$ M. spretus mouse. The interstrain cross $(\mathrm{Cm} /+$ $\mathrm{C} 3 \mathrm{H} / \mathrm{HeSnJ} \times+/+\mathrm{C} 57 \mathrm{BL} / 6 \mathrm{~J}) \mathrm{dem}-$ onstrated that Pax-1 is also intact in coloboma mice $(c)$, as the $\mathrm{C} 3 \mathrm{H} / \mathrm{HeSnJ}$ RFLP (arrow) is present in the $\mathrm{Cm} /+$ hybrid mouse.
mRNA expression resulted in lower SNAP-25 protein expression. To quantitate the difference in SNAP-25 protein expression between $\mathrm{Cm} /+$ mice and $+/+$ littermates, increasing masses of brain proteins from control and mutant mice were blotted onto nitrocellulose, reacted with antibody directed against the SNAP-25 carboxy terminus (Oyler et al., 1989), and visualized with iodinated protein A. Comparison of the autoradiographs as arbitrary film densitometric units against protein mass revealed that SNAP-25 protein in brain extracts of the $\mathrm{Cm} /+$ mouse mutants was half that of the $+/+$ mice, suggesting that coloboma mice express half the normal levels of SNAP-25 protein (Fig. 7). Thus, the half Snap gene dose in coloboma mice results in 50\% SNAP-25 protein expression.

Coloboma mouse behavioral phenotype. The $\mathrm{Cm}$ mutation is semidominant wherein the heterozygous state $(\mathrm{Cm} /+)$ results in a mutant phenotype, while homozygous $(\mathrm{Cm} / \mathrm{Cm})$ mice are not viable and die during embryogenesis. It has been suggested that this lethality occurs prior to embryonic day 6 (Theiler and Varnum, 1981). Heterozygous coloboma mouse mutants were readily identified at postnatal day 14 by their small eyes, which result from the failure of the cornea and lens epithelium to separate during development (Theiler and Varnum, 1981). These mice also displayed head bobbing as described previously by Searle (1966). Additionally, we noted that these mice were extremely active.

To quantitate better the hyperactivity exhibited by coloboma mice, the spontaneous locomotor activity of $+/+$ and $\mathrm{Cm} /+$ littermates on a $\mathrm{C} 3 \mathrm{H} / \mathrm{HeSnJ}$ background was recorded in automated open field activity cages over $24 \mathrm{hr}$ starting at 10:00 A.M. All mice used in the behavioral tests were obtained from The Jackson Laboratory where they were identified as $\mathrm{Cm} /+$ or $+/+$ mice using eye morphology as the phenotypic criterion for genotype determination. Both mutant and control littermates habituated to the cages within the first $150 \mathrm{~min}$ of the testing session (Fig. 8). Coloboma mice appeared to have a normal circadian rhythm that paralleled control littermate activity, with increased activity at night and occasional bursts of daytime activity associated with eating. $\mathrm{Cm} /+$ mice were significantly more active than their $+/+$ littermates (two-factor ANOVA, $p<0.005$ ), with activity counts at night more than three times control activity. In fact, the nocturnal locomotor activity of some mutants exceeded 10 times that of their control littermates. Although coloboma mice exhibited enhanced locomotor activity, no difference was observed between controls and mutants in time spent quiescent (Student's $t$ test, $p>0.05$ ), as assessed by number of $15 \mathrm{~min}$ intervals per mouse during which no photocell beams were broken. Thus, these mutants are extraordinarily active while maintaining normal sleep/wake patterns.

\section{Discussion}

The genetic analysis presented here mapped Snap to the same region of Chr 2 as the $\mathrm{Cm}$ mutation in coloboma mice. $\mathrm{Cm}$ was previously mapped to $\mathrm{Chr} 2$ using agouti ( $a$ ) and wellhaarig (we) 

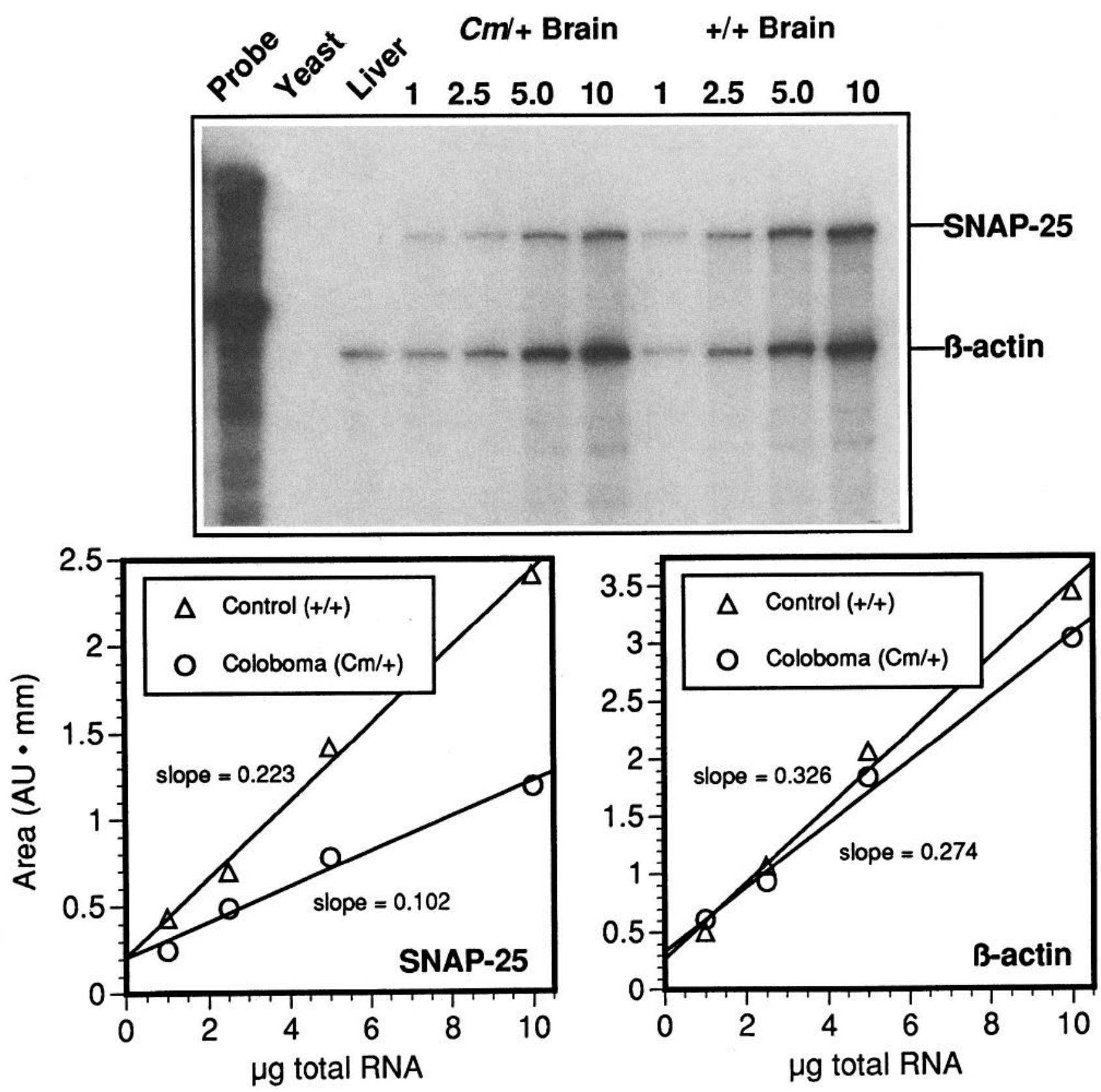

Figure 5. Ribonuclease protection assay of SNAP-25 mRNA expression. Increasing masses of total RNA extracted from the brains of a control $(+/+)$ mouse and coloboma $(\mathrm{Cm} /+)$ littermate were assayed with ${ }^{32} \mathrm{P}$-labeled cRNA probes to SNAP-25 or $\beta$-actin. SNAP-25 RNA expression in $\mathrm{Cm} /+$ brain is approximately $50 \%$ lower than in $+/+$ brain, while $\beta$-actin expression is comparable between control and mutant. Yeast and liver RNAs were used as negative controls.

as markers (Snell and Bunker, 1967; H. Bunker in The Jackson Laboratory GBASE data base). Recombination frequencies between $\mathrm{Cm}, a$, and we placed the $\mathrm{Cm}$ locus between these two loci (Fig. 1a). In this study, we have mapped the Snap gene to this same region approximately equidistant between $H d c$ and $E m v-15$ and demonstrated that Snap is deleted in the $\mathrm{Cm}$ mutation.

The previous linkage studies coupled with the molecular genetic data presented herein confirm that the morphologic and neurologic abnormalities exhibited by coloboma mice are attributable to the mutant $\mathrm{Cm}$ deletion, which includes the Snap gene. The complex phenotype exhibited by coloboma mice in- cludes head bobbing, opthalmic malformation, and hyperactivity; these traits have been found to cosegregate consistently in a Mendelian fashion with the $\mathrm{Cm}$ mutation. In breeding this mutant strain through $+/+\times \mathrm{Cm} /+$ matings, we have observed approximately $50 \%$ of the offspring exhibiting head bobbing, opthalmic deformation, and hyperactivity (E. J. Hess and M. C. Wilson, unpublished observations), consistent with the 1:1 segregation ratio expected for a single genetic locus. Similarly, progeny of interspecies $(M . m$. musculus $\times M$. spretus) crosses demonstrated co-inheritance of the Snap deletion with opthalamic dysmorphology. Additionally, in open field tests of motor activity, $\mathrm{Cm} /+$ mutants identified solely on the basis of op- 
SNAP-25
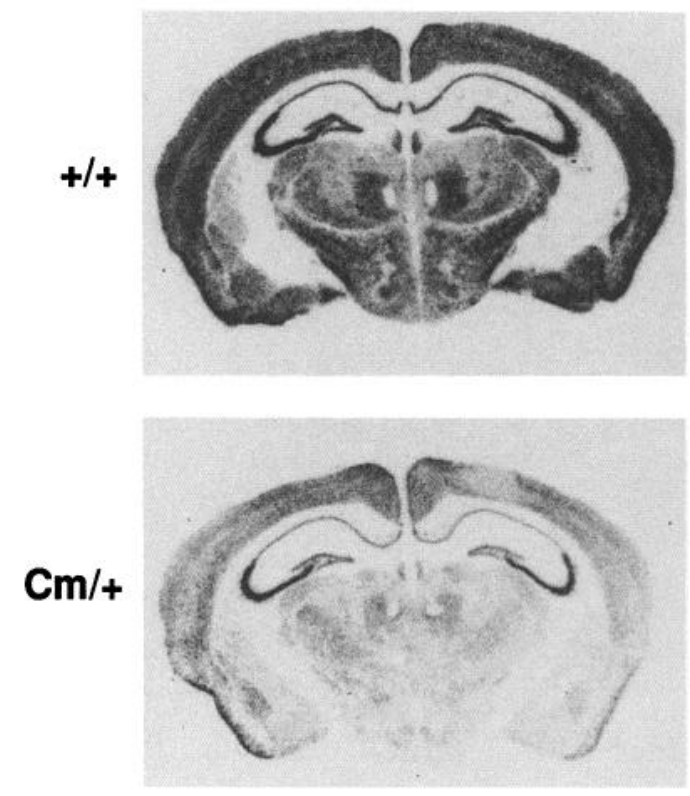

B-Amyloid
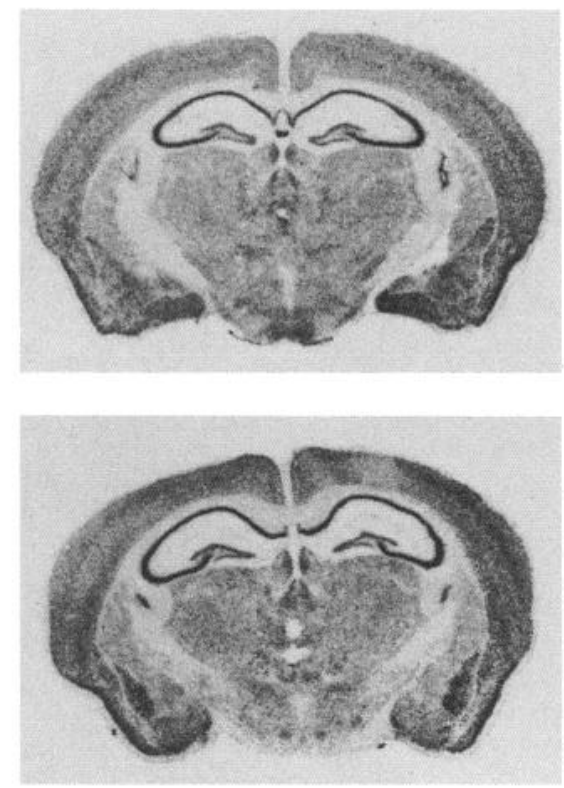

Figure 6. Localization of SNAP-25 and $\beta$-amyloid precursor protein mRNA in control $(+/+)$ and coloboma $(\mathrm{Cm} /$ $+)$ mouse brains. Coronal sections (20 $\mu \mathrm{m})$ from mutant and normal littermates were processed for in situ hybridization and apposed to film for 60 hr. Experiments were performed on 810 -week-old male mouse mutants $(n=$ 2); wild-type $\mathrm{C} 3 \mathrm{H} / \mathrm{HeSnJ}$ age- and sexmatched littermates were used as controls. thalmic deformation were consistently hyperactive in comparison to their normal littermates. These observations suggest that the phenotypic and genotypic abnormalities in coloboma mice result from a mutation that segregates as a single genetic locus.

Consistent with $\mathrm{Cm} /+$ mice being hemizygous for Snap, $50 \%$ of the normal Snap gene dose was detected in coloboma mice by genomic DNA slot blot analysis. Although the Snap gene dosage in coloboma mice was half that of controls, Snap RFLPs were not observed between coloboma and control mouse DNA, suggesting that the entire Snap gene is deleted in the coloboma mutation. Preliminary studies have suggested that the Snap gene consists of as many as eight or more exons dispersed over greater than $50 \mathrm{~kb}$ of genomic DNA (Bark et al., 1990). Although the entire Snap gene is deleted in the coloboma mutation, the coloboma karyotype assessed by G-banded chromosomes is normal (Davisson and Lewis, 1990), suggesting that the coloboma mutation is not a gross chromosomal abnormality.
At present, the extent of the coloboma deletion is unknown; in fact, it could encompass one or more genes in addition to Snap. Analysis of RFLP segregation in the mouse backcrosses localized the Snap gene to a region of mouse $\mathrm{Chr} 2$, where several other genes have been mapped. Genes mapping in the same region as Snap include $I l$-la (interleukin 1A), $P r n-p$ (prion protein), Bmp-2a (bone morphogenetic protein-2a), and Pax-1 (paired box gene-1), suggesting that the human Snap gene resides in the syntenic region of human Chr 20p (Copeland and Jenkins, 1991). Although further studies aimed at providing a physical map of this locus will be required to define precisely the extent of the $C m$ deletion, $P a x-1$ and $B m p-2 a$, cloned markers mapping in the same region as Snap, are not deleted. These data together with the observation that the deletion is not detectable microscopically suggest that this deletion likely includes $5 \mathrm{~cm}$ or less of the mouse genome.

The embryonic lethality observed on the homozygous $\mathrm{Cm} /$ $\mathrm{Cm}$ mutant may result from the deletion of both Snap genes.
Figure 7. SNAP-25 protein expression in control $(+/+)$ and coloboma $(\mathrm{Cm} /+)$ mice. Increasing masses of brain protein prepared from mutant and phenotypically normal littermates were blotted onto nitrocellulose, reacted with anti-SNAP-25 antibody, visualized using ${ }^{125} \mathrm{I}$ protein $\mathrm{A}$, and apposed to $\mathrm{x}$-ray film. Autoradiographs were quantitated using a laser densitometer, and the arbitrary absorbance units were plotted against the mass of brain protein loaded in the slot $(n=2)$. SNAP- 25 protein expression in the coloboma $(\mathrm{Cm} /+)$ brain was approximately $50 \%$ lower (slope $=0.147)$ than in the normal $(+/$ + ) brain (slope $=0.343$ ).

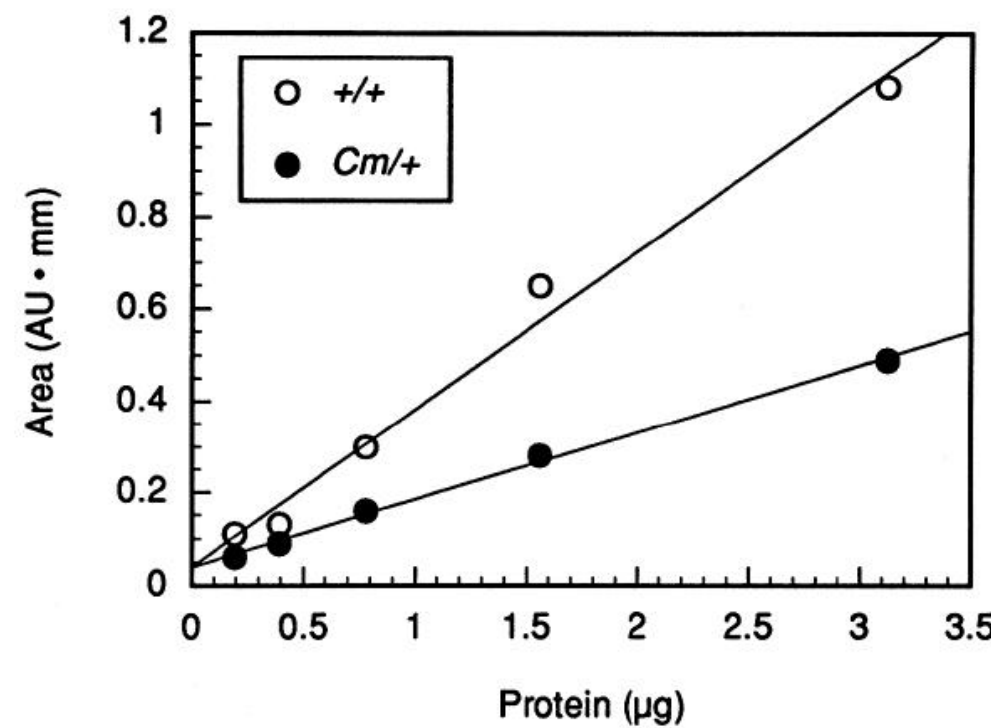




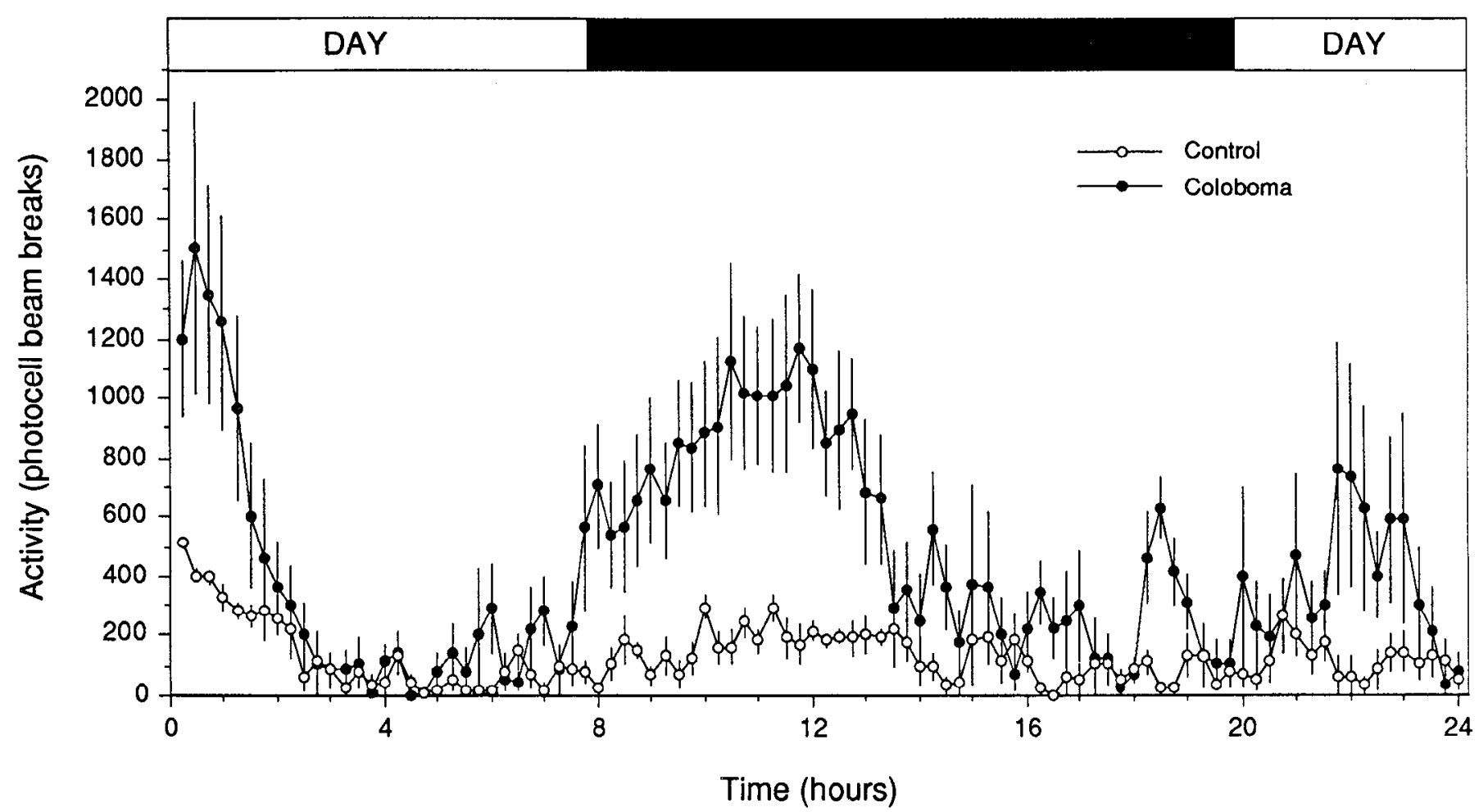

Figure 8. Spontaneous locomotor activity in $+/+(n=5)$ and $C m /+(n=5)$ littermates over 24 hr. Recordings were performed in automated open field activity chambers starting at 10:00 A.M. with photocell beam breaks accumulated every 15 min. The spontaneous activity of coloboma mice was significantly greater than control littermates $(p<0.005$, two-way repeated-measures ANOVA). However, time spent quiescent was not significantly different between control and coloboma mice $(p>0.05$, Student's $t$ test). Data represent mean \pm SEM.

SNAP-25 protein expression has been detected in developing rat brain as early as embryonic day 15 (Oyler et al., 1991) and may be expressed earlier in embryogenesis. In fact, SNAP-25 expression is coincident with synaptogenesis (Catsicas et al., 1991) and neurite differentiation (Sanna et al., 1991), and is a major component of presynaptic terminals. Given the close association between SNAP-25 expression and synaptogenesis, the homozygous Snap deletion mutation may impair the development of the nervous system and contribute to the death of the developing embryo.

The half Snap gene dose observed in $\mathrm{Cm} /+$ mice was reflected in a $50 \%$ reduction in both SNAP- $25 \mathrm{mRNA}$ and protein expression. These data suggest that transcription and subsequent translation of the remaining Snap gene in coloboma mice do not compensate for the loss of the Snap gene on the mutant chromosome. The reduction in SNAP-25 protein expression in coloboma mice may ultimately be reflected in the $\mathrm{Cm} /+$ phenotype. As the eye is derived from neural crest cells and the retina expresses SNAP-25 (Catsicas et al., 1991), it is possible that the abnormal opthalmic phenotype results from a SNAP25 deficiency. Additionally, the neuron-specific expression of SNAP-25 may play a role in the coloboma mouse behavioral abnormalities such as head bobbing and extreme hyperactivity. The presynaptic localization of SNAP-25 in nerve terminals implicates SNAP-25 in neural transmission. Aberrant SNAP25 protein concentrations within the nerve terminal may disrupt intercellular signaling to the extent that the corrupt synaptic function is ultimately manifested as hyperactivity. Alternatively, half gene doses of other genes possibly encompassed by the deletion may also contribute to the morphological and behavioral abnormalities observed in coloboma mice.
The profound spontaneous hyperactivity exhibited by coloboma mice exceeded three times the activity of the control littermates, with the most active mutants approaching 10 times control mouse activity. Comparable levels of hyperactivity have also been observed in mice after ingesting lead for $40 \mathrm{~d}$ (Silbergeld and Goldberg, 1974). In other animal models of hyperactivity, the enhanced locomotor activity is not often so obvious. Activity in weaver mice, a neurological mouse mutant with severe dopaminergic deficits and cerebellar atrophy, is approximately 1.5 times greater than control littermates (Schmidt et al., 1982) and is confounded by cerebellar-induced ataxia. Similarly, experimental models of hyperactivity in rat such as neonatal 6-hydroxydopamine treatment and the SHR exhibit locomotor activity 1.5-2 times greater than controls (Shaywitz et al., 1976; Knardahl and Sagvolden, 1979; Wultz et al., 1990). In contrast to these animal models of hyperactivity, the coloboma deletion mutation induces extreme spontaneous hyperactivity without chemical intervention or gross neuropathology.

Several characteristics of coloboma mice parallel the hyperactivity syndrome ADHD, a common pediatric disorder characterized by inattention, impulsivity, and hyperactivity. Like children with ADHD (Greenhill et al., 1983), coloboma mice are hyperactive during their active (nocturnal) phase and otherwise exhibit normal patterns of sleep. Additionally, although the etiology of ADHD is unknown, there is evidence that suggests that ADHD may have a genetic basis (Deutsch et al., 1982; Biederman et al,, 1986). As pyschostimulants, such as methylphenidate, are effective in ameliorating the disorders of activity in many affected children, an animal model of ADHD should appropriately exhibit similar responses to these drugs. Further investigations characterizing the behavioral response of colo- 
boma mice to psychostimulants are in progress to determine whether this mouse mutant is an accurate model of ADHD.

The Snap gene is clearly deleted in coloboma mice, and these data suggest that the coloboma mutant may represent a heritable model of hyperactivity. It is unclear if other genes are included in this deletion and how they influence the mutant phenotype. Indeed, if several genes are involved in the coloboma mouse phenotype, it may be possible to dissect the mutant phenotypes according to gene. For example, one gene may contribute to the ocular deformation whereas another may play a role in the hyperactivity exhibited by these mice. Thus, in the future, it may be possible to engineer a mouse that exhibits only the hyperactivity without head bobbing or ocular deformation.

\section{References}

Adamson MC, Silver J, Kozak CA (1991) The mouse homolog of the gibbon ape leukemia virus receptor: genetic mapping and a possible receptor function in rodents. Virology 183:778-781.

Bark IC, Larhammar D, Wilson MC (1990) Isolation and characterization of the chicken gene for SNAP-25. Soc Neurosci Abstr 16:355.

Biederman J, Munir K, Knee D, Habelow W, Armentano M, Autor S, Hoge SK, Waternaux C (1986) A family study of patients with attention deficit disorder and normal controls. J Psychiatr Res 20: 263-274.

Catsicas S, Larhammar D, Blomqvist A, Sanna PP, Milner RJ, Wilson MC (1991) Expression of a conserved cell-type-specific protein in nerve terminals coincides with synaptogenesis. Proc Natl Acad Sci USA 88:785-789.

Chirgwin JM, Przybyla AE, MacDonald RJ, Rutter WJ (1979) Isolation of biologically active ribonucleic acid from sources enriched in ribonuclease. Biochemistry 18:5294-5299.

Copeland NG, Jenkins NA (1991) Development and applications of a molecular genetic linkage map of the mouse genome. Trends Genet 7:113-118.

Davisson MT, Lewis SE (1990) Chromosome aberrations associated with induced mutations: effect on mapping new mutations. In: Branbury report 34, Biology of mammalian germ-cell mutagenesis (Allen JW et al., eds), pp 195-206. Cold Spring Harbor, NY: Cold Spring Harbor Laboratory.

Deutsch CK, Swanson JM, Bruell JH, Cantwell DP, Weinberg F, Baren $M$ (1982) Overrepresentation of adoptees in children with the attention deficit disorder. Behav Genet 12:231-238.

Deutsch U, Dressler GR, Gruss P (1988) Pax 1, a member of a paired box homologous murine gene family, is expressed in segmented structures during development. Cell 53:617-625.

Geddes JW, Hess EJ, Hart RA, Kesslak JP, Cotman CW, Wilson MC (1990) Lesions of hippocampal circuitry define synaptosomal-associated protein-25 (SNAP-25) as a novel presynaptic marker. Neuroscience 38:515-525.

Green EL (1981a) Breeding systems. In: The mouse in biomedical research, Vol 1 (Foster HL, Small JD, Fox JG, eds), pp 91-104. London: Academic.

Green EL (1981b) Genetics and probability in animal breeding experiments, pp 77-113. New York: Oxford UP.

Green MC (1981) Catalog of mutant genes and polymorphic loci. In: Genetic variants and strains of the laboratory mouse (Green MC, ed), pp 8-279. New York: Gustav Fischer.

Greenhill L, Puig-Antich J, Goetz R, Hanlom C, Davies M (1983) Sleep architecture and REM sleep measures in prepubertal children with attention deficit disorder with hyperactivity. Sleep 6:91-101.
Hillyard AL, Doolittle DP, Davisson MT, Roderick TH (1991) Locus map of the mouse. Mouse Genome 89:16-30.

Hoggan MD, Halden NF, Buckler CE, Kozak CA (1988) Genetic mapping of the mouse c-fms proto-oncogene to chromosome 18 . J Virol 62:1055-1056.

Joseph DR, Sullivan PM, Wang Y-M, Kozak C, Fenstermacher DA, Behrendsen ME, Zahnow CA (1990) Characterization and expression of the complementary DNA encoding rat histidine decarboxylase. Proc Natl Acad Sci USA 87:733-737.

Knardahl S, Sagvolden T (1979) Open-field behavior of spontaneously hypertensive rats. Behav Neural Biol 27:187-200.

Kozak CA, Peyser M, Krall M, Mariano TM, Kumar CS, Pestka S, Mock BA (1990) Molecular genetic markers spanning mouse chromosome 10. Genomics 8:519-524.

Loewy A, Liu W-S, Baitinger C, Willard M (1991) The major ${ }^{35} \mathrm{~S}-$ methionine-labeled rapidly transported protein (superprotein) is identical to SNAP-25, a protein of synaptic terminals. J Neurosci 11: 3412-3421.

Lovett M, Cheng ZY, Lamela EM, Yokoe T, Epstein CJ (1987) Molecular markers for the agouti coat color locus of the mouse. Genetics 115:747-754

Lyon MF, Kirby MC (1991) Mouse chromosome atlas. Mouse Genome 89:37-59.

Lyons KM, Pelton RW, Hogan BLM (1989) Patterns of expression of murine Vgr-1 and BMP-2a RNA suggest that transforming growth factor- $\beta$-like genes coordinately regulate aspects of embryonic development. Genes Dev 3:1657-1668.

Oyler GA, Higgins GA, Hart RA, Battenberg E, Billingsley M, Bloom FE, Wilson MC (1989) The identification of a novel synaptosomalassociated protein, SNAP-25, differentially expressed by neuronal subpopulations. J Cell Biol 109:3039-3052.

Oyler GA, Polli JW, Wilson MC, Billingsley ML (1991) Developmental expression of the synaptosomal associated protein (SNAP-25) in rat brain. Proc Natl Acad Sci USA 88:5247-5251.

Roffler-Tarlov S, Graybiel A (1984) Weaver mutation has differential effects on the dopamine-containing innervation of the limbic and nonlimbic striatum. Nature 307:62-66.

Sanna PP, Bloom FE, Wilson MC (1991) Dibutyryl-cAMP induces SNAP-25 translocation into the neurites in PC12. Dev Brain Res 59: 104-108.

Schmidt MJ, Sawyer BD, Perry KW, Fuller RW, Foreman MM, Ghetti B (1982) Dopamine deficiency in the weaver mutant mouse. J Neurosci 2:376-380.

Searle AG (1966) New mutants, Vol 2, Coloboma. Mouse News Lett 35:27.

Shaywitz BA, Yager RD, Klopper JH (1976) Selective brain dopamine depletion in developing rats: an experimental model of minimal brain dysfunction. Science 191:305-307.

Silbergeld EK, Goldberg AM (1974) Lead-induced behavioral dysfunction: an animal model of hyperactivity. Exp Neurol 42:146-157.

Siracusa LD, Abbott CM (1991) Mouse chromosome 2: a linkage map. Mouse Genome 1:S18-S41.

Snell GD, Bunker HP (1967) [Coloboma linkage]. Mouse News Lett $37: 34$.

Theiler K, Varnum DS (1981) Development of coloboma $(\mathrm{Cm} /+$ ), a mutation with anterior lens adhesion. Anat Embryol 161:121-126.

Wilson MC, Higgins GA (1989) In situ hybridization. In: Neuromethods, Vol 16, Molecular neurobiological techniques (Boulton AA, Baker GB, Campagnoni AT, eds), pp 239-284. Clifton, NJ: Humana. Wultz B, Sagvolden T, Moser EI, Moser M-B (1990) The spontaneously hypertensive rat as an animal model of attention-deficit hyperactivity disorder: effects of methylphenidate on exploratory behavior. Behav Neural Biol 53:88-102. 